Beata Żołędowska-Król

\title{
Biblioteka jako miejsce pracy w ocenie pracowników Przegląd badań
}

STRESZCZENiE: Celem artykułu jest zidentyfikowanie czynników wpływających na satysfakcję zawodową bibliotekarzy. Na podstawie „Bibliografii Analitycznej Bibliotekoznawstwa i Informacji Naukowej" dokonano przeglądu piśmiennictwa zagranicznego poświęconego badaniom zadowolenia pracowników bibliotek. W drugiej części przedstawiono polską literaturę fachową z tego zakresu. Omówiono także inicjatywy bibliotek polskich, które podjęły badania nad satysfakcją zawodową swoich pracowników, m.in. Biblioteki Uniwersytetu Warszawskiego oraz Biblioteki Uniwersytetu Pedagogicznego w Krakowie.

SŁoWA KLUCzowE: „Bibliografia Analityczna Bibliotekoznawstwa i Informacji Naukowej", Biblioteka Uniwersytecka w Warszawie, Biblioteka Uniwersytetu Pedagogicznego w Krakowie, pracownicy bibliotek, przegląd piśmiennictwa, satysfakcja zawodowa

\section{Wprowadzenie}

Z miany zachodzące w życiu społecznym i gospodarczym oraz szybkie postępy w nauce, pracy i technice wymagają od ludzi coraz wyższych kwalifikacji oraz lepszego rozumienia problemów biblioteki. Rośnie także znaczenie inicjatywy i kreatywności bibliotekarzy oraz ich zaanga- 
żowania w realizację wspólnej wizji. Współczesna placówka, jeżeli chce sprostać tym wymaganiom, musi postawić na jakość kierowania ludźmi. Zadaniem kierownictwa jest więc tworzenie takiego klimatu organizacyjnego, w którym istnieją warunki i zachęty do lepszej pracy, przezwyciężania dezintegracji, pobudzania indywidualnej aktywności i zbiorowej zaradności.

Klimat organizacyjny jest kształtowany przez wiele różnorodnych czynników, zarówno wewnętrznych, jak i zewnętrznych, o różnej sile i znaczeniu, które wpływają na odczucia i postawy pracowników, ich stopień zadowolenia i identyfikowania się z celami biblioteki. Jak zauważa Józef Penc ${ }^{1}$, różna kompozycja tych czynników może stanowić dla pracownika podstawę do interpretowania i rozumienia wielu sytuacji organizacyjnych, w jakich się znajduje i jakim musi sprostać. Łatwo zauważyć, że chociaż dla kształtowania klimatu ważny jest sposób traktowania przez bibliotekę swego otoczenia i wrażliwość na zachodzące w nim zmiany, to odnosi się on przede wszystkim do wnętrza biblioteki, a więc do sposobu funkcjonowania w niej pracowników i sposobu ich myślenia oraz działania, a także oczekiwań wobec biblioteki jako miejsca pracy. Podstawą kształtowania dobrej atmosfery w pracy jest więc zapewnienie pewnej harmonii między współdziałającymi ludźmi, wyrażającej się dobrymi stosunkami w grupie i sprawną komunikacją między zwierzchnikami a pracownikami.

\section{Zadowolenie z pracy jako postawa wobec biblioteki}

Postawy pracowników odnoszące się do zadowolenia z pracy i zaangażowanie organizacyjne mają istotne znaczenie $w$ dziedzinie zachowań organizacyjnych i w praktyce zarządzania zasobami ludzkimi. Tematyka satysfakcji z miejsca pracy jest przedmiotem zainteresowania badaczy wielu dyscyplin: psychologii, socjologii, nauk o zarządzaniu. Dorobek w dziedzinie bibliotekoznawstwa wydaje się bardziej skromny. W większości tekstów, w których poruszono temat badań satysfakcji, skupiono się - i słusznie - na użytkownikach bibliotek. Analizuje się ich oczekiwania wobec usług i pracowników, odczucia i oceny. Trzeba jednak pamiętać, że na jakość usług wpływa też satysfakcja pracownika, który te usługi

1 J. Penc, Kreowanie zachowań w organizacji. Konflikty i stresy pracownicze. Zmiany i rozwój organizacji, Warszawa 2001, s. 87. 
świadczy. Nasuwa się więc pytanie, jakie materialne i pozamaterialne elementy wpływają na zadowolenie bibliotekarzy.

O satysfakcji z pracy stanowią pozytywne i negatywne uczucia oraz postawy wobec pracy. Zależy ona od wielu czynników związanych z pracą, poczynając od miejsca parkowania samochodu do poczucia samospełnienia przy realizacji codziennych zadań. Na zadowolenie z pracy mogą również wpływać czynniki indywidualne, jak wiek, staż pracy, stan zdrowia, aspiracje czy zainteresowania. Warto też podkreślić, że satysfakcję pracowników odnosi się do sfery oczekiwań zatrudnionych osób, a więc jest ona odczuciem subiektywnym i nie musi odzwierciedlać rzeczywistości. Pracownicy na podstawie własnych doświadczeń życiowych, obserwacji oraz wyznawanego systemu wartości dokonują oceny zadowolenia z pracy w danej bibliotece. Jak wspomniano, wielu badaczy organizacji poszukuje związku pomiędzy wartościami, które ludzie cenią w pracy, a zadowoleniem z pracy i motywacją do pracy. Wśród nich warto wymienić Urszulę Gros, która wyodrębniła trzy grupy czynników wpływających na satysfakcję personelu: organizacyjne, społeczne i osobiste ${ }^{2}$.

Czynniki organizacyjne związane są z treścią pracy, rodzajem wykonywanych zadań, możliwością awansu na bardziej wyspecjalizowane stanowiska, wysokością wynagrodzenia i innych świadczeń, stosowaną przez kierownictwo polityką w zakresie funkcjonowania i rozwoju biblioteki. Z kolei czynniki społeczne odnoszą się do istniejącego poziomu spójności celów różnych pracowników, wyrażanego w harmonii działania, zakresu zgodności postępowania z etyką zawodową i osobistą, współpracy z innymi pracownikami, którzy mogą być pomocni i życzliwi, chętni do zastępstwa, kontaktów z przełożonym, który służy zawodową pomocą i wsparciem, a także sam dba o własny rozwój. Do czynników tych należeć będzie zatem kultura organizacyjna, zgodność z etyką zawodową, współpraca ze zwierzchnikiem, kontakty ze współpracownikami, a także relacje z użytkownikami. Trzecia grupa czynników - osobistych, nawiązuje natomiast do wieku, płci, doświadczenia, aspiracji oraz korzyści pozapłacowych (np. możliwości korzystania z poczty e-mail, Internetu, księgozbioru).

Elementy te powodują powstawanie różnych potrzeb u różnych ludzi (dobra płaca, potrzeba szacunku zwierzchników i kolegów, stabilność zatrudnienia) i przyczyniają się do niejednolitej reakcji na poziom ich

\footnotetext{
${ }^{2}$ U. Gros, Zachowania organizacyjne w teorii i praktyce zarządzania, Warszawa 2003,
} s. 115. 
zaspokojenia. W rezultacie oddziaływania różnych czynników pracownik wyrabia sobie opinię o nich, zwłaszcza o czynnikach organizacyjnych i społecznych, które wywołują w nim jakiś poziom satysfakcji3 ${ }^{3}$.

\section{Badania satysfakcii zawodowej bibliotekarzy}

Aby określić czynniki wpływające na satysfakcję zawodową bibliotekarzy, warto odnieść się do teorii i badań z zakresu bibliotekoznawstwa. W tym celu dokonano przeglądu piśmiennictwa zagranicznego poświęconego zadowoleniu pracowników bibliotek. Analizie poddano teksty zarejestrowane w „Bibliografii Analitycznej Bibliotekoznawstwa i Informacji Naukowej" (dalej: BABIN) w latach 1987-2010. Wśród artykułów dominują te o charakterze empirycznym, w których zamieszczono badania nastrojów pracowniczych. Drugą, mniej liczną grupę stanowią teksty teoretyczne, omawiające zwłaszcza teorie motywacyjne. W niniejszym artykule uwzględniono jedynie tę pierwszą grupę. Otwiera ją tekst opublikowany w $1987 \mathrm{r}^{4}$ Przedstawiono w nim wyniki badań, którymi objęto anonimowo trzy biblioteki uniwersyteckie w Stanach Zjednoczonych. Wykazano, że najbardziej zadowoloną kategorię pracowników stanowiły osoby starsze stażem, deklarujące tym samym chęć pozostania w swojej placówce na stałe. Najwyższy poziom satysfakcji zawodowej osiągali pracownicy działów informacji, na co miał wpływ - według opinii respondentów - stosunkowo niski poziom zrutynizowania pracy.

Kolejny artykuł również odnosi się do badań zrealizowanych w bibliotekach szkół wyższych w Stanach Zjednoczonych ${ }^{5}$. Pomiarem objęto dwie grupy pracowników: bibliotekarzy oraz personel pomocniczy bibliotek Uniwersytetu Kalifornijskiego. Druga grupa zatrudnionych wykazała dużo mniejszy poziom zadowolenia z wykonywanej pracy. Wpływ na ten stan rzeczy miała przede wszystkim możliwość awansu, a raczej jej brak, częste zmiany zakresu czynności, brak wpływu na działalność biblioteki oraz wysokość wynagrodzenia.

${ }^{3}$ B. Żołędowska-Król, Badanie opinii pracowników jako instrument wspomagający zarządzanie relacjami wewnętrznymi w bibliotece, [w:] Zarządzanie kadrami w bibliotece, pod red. J. Kamińskiej, B. Żołędowskiej-Król, Warszawa 2008, s. 54-55.

${ }^{4}$ B. P. Lynch, J. A. Verdin, Job satisfaction in libraries, a replication, „The Library Quarterly" vol. 57: 1987, no. 2, s. 190-202.

5 P. A. Kreitz, A. Ogden, Job responsibilities and job satisfaction at the University of California libraries, „College and Research Libraries” vol. 51: 1990, no. 4, s. 297-312. 
Tematykę postaw wobec pracy wśród personelu pomocniczego podjęto w następnych dwóch tekstach. W 1990 r. ukazał się artykuł autorstwa Donny K. Fitch ${ }^{6}$, w którym przedstawiono wyniki badań przeprowadzonych $\mathrm{w}$ bibliotekach akademickich Alabamy. W ankiecie uwzględniono takie czynniki, jak: wielkość miasta, płeć, ruchomy czas pracy, rodzaj i struktura instytucji, jej historia, personel, stan automatyzacji, funkcje biblioteki, metody kontroli pracy. Rezultaty badań wykazały, że czynniki demograficzne nie mają wpływu na satysfakcję z pracy, wpływ odwrotnie proporcjonalny do poziomu satysfakcji ma natomiast wielkość instytucji. Zauważono wpływ płci na poziom zadowolenia, gdyż większą satysfakcję z pracy odczuwały kobiety. Analizowano także zależność poziomu satysfakcji od osiąganych dochodów, stażu pracy, możliwości awansu, jakości pracy, odczuwanych stresów.

Zagadnienie postrzegania własnej roli przez personel pomocniczy w relacji do wykwalifikowanych bibliotekarzy podjęto rok później. Przeprowadzone w bibliotekach brytyjskich badania wykazały duże poczucie frustracji tej grupy pracowników, wynikające ze sztywnej hierarchii służbowej, prowadzącej do ogromnej bariery pomiędzy nimi a wykwalifikowanymi bibliotekarzami. Personel pomocniczy czuł się niedoceniany, oceniał swoją pracę jako zbyt rutynową, niepozwalającą na wykorzystanie ich możliwości i zdolności, uniemożliwiającą awans i niedającą pola do twórczego myślenia.

Kolejne badania, przeprowadzone w $1994 \mathrm{r}^{8}$, miały na celu określenie specyfiki zawodowej amerykańskich bibliotekarzy pracujących we wszystkich typach bibliotek. Uwzględniono również dane statystyczne dotyczące czasu pracy i wynagrodzenia. Ogółem zadowolonych z pracy było $81 \%$ mężczyzn i $86 \%$ kobiet, przy czym respondenci raczej pesymistycznie postrzegali swoje perspektywy rozwoju i awansu.

W 1997 r. opublikowano wyniki badania zrealizowanego wśród pracowników bibliotek uniwersyteckich w Kanadzie ${ }^{9}$. Respondenci, podzie-

${ }^{6}$ D. K. Fitch, Job satisfaction among library support staff in Alabama academic libraries, „College and Research Libraries” vol. 51: 1990, no. 4, s. 313-320.

7 A. P. N. Thapisa, The labourers who shift things around, the professionalisation of library and information work and its impact on library assistants' perceptions of their work, „Library Management” vol. 12: 1991, no. 6, s. 28-39.

8 E. S. Lifer, Are you happy in your job? «LJ»'s exclusive report, «Library Journal» career survey, part 2: job satisfaction, „Library Journal” vol. 119: 1994, no. 18, s. 44-49.

${ }_{9}$ G. L. Leckie, J. Brett, Job satisfaction of Canadian university librarians, a national survey, „College and Research Libraries” vol. 58: 1997, no. 1, s. 31-47. 
leni na trzy grupy: bibliotekarze o statusie akademickim, równorzędnym do kadry nauczającej, pozostali bibliotekarze i kadra kierownicza, oceniali trzydzieści dwie zmienne obejmujące podstawowe aspekty pracy. Zaliczono do nich m.in. zakres obowiązków, możliwość samodzielnego podejmowania decyzji w bibliotece, uczestnictwo w zarządzaniu biblioteką, obciążenie pracą, uczestnictwo w procesie podejmowania decyzji na uczelni, możliwości awansu, zarobki. Średnia ocena zadowolenia z pracy wyniosła 3,59 w pięciopunktowej skali, przy czym za przynoszące najwięcej satysfakcji, zwłaszcza w grupie szeregowych bibliotekarzy, uznano kontakty z użytkownikami, samodzielne podejmowanie decyzji, a za stosunkowo mniej ważne możliwości awansu czy obciążenie pracą. Wyniki świadczą o tym, że badani za najważniejsze uznali aspekty pracy związane z bibliotekarstwem jako zawodem, a za znacznie mniej ważne - cechy specyficzne dla pracy w danym środowisku. Ponadto bibliotekarze o statusie akademickim większą wagę przywiązują do pozycji na uczelni i możliwości uczestnictwa w jej życiu. Dla bibliotekarzy sprawujących funkcje kierownicze szczególnie istotne jest uczestnictwo w procesie podejmowania decyzji i planowania, styl zarządzania biblioteką czy możliwości awansu. Obie te grupy osiągają nieco wyższą satysfakcję z pracy niż szeregowi bibliotekarze, na co wpływa większe uczestnictwo w procesie podejmowania decyzji.

Kolejny tekst przyniósł analizę porównawczą badań przeprowadzonych wśród bibliotekarzy Biblioteki Naukowej Twerskiego Państwowego Uniwersytetu w Rosji w latach 1992 i $1997^{10}$. Osoby ankietowane w 1997 r., w stosunku do badań z 1992 r., rzadziej deklarowały, że wybrały zawód, kierując się „miłością do książek i chęcią służenia ludziom”, $13 \%$ badanych po prostu nie miało innych propozycji pracy (w $1992 \mathrm{r}$. nie było tego rodzaju wypowiedzi). Reforma systemu płac zadecydowała o usatysfakcjonowaniu zarobkami (w każdej grupie o $20 \%$ więcej zadowolonych). Zwiększyło się znacznie zadowolenie ze współpracy z kolegami, na co miała wpływ konieczność pracy zespołowej, a zmniejszyło - z posiadanych umiejętności i kwalifikacji. Aż 37\% ankietowanych narzekało na brak potrzebnej wiedzy (w 1992 r. - 22\%). W 1992 r. 81\% badanych oceniało swoje kwalifikacje jako wystarczające, a w $1997 \mathrm{r}$. już tylko 63\%. Na takie wyniki wpłynęła konieczność zaadaptowania się do pracy w systemie komputerowym i ukończenia licznych kursów. W 1992 r.

${ }^{10}$ E. I. Berezkina, „Bibliotekar' v biblioteke”, rezul'taty sociologičeskogo issledovanija, „Bibliotekovedenie” 1998, nr 2, s. 71-73. 
przyczyny konfliktów upatrywano w zbyt małej wiedzy i postawie studentów; pięć lat później coraz częściej w braku przygotowania bibliotekarzy z zakresu psychologii i pedagogiki.

Wyniki badań dotyczących zadowolenia z pracy bibliotekarzy angielskich szkół wyższych w Quebecu prezentuje artykuł Eino Sierpe ${ }^{11}$. Jako narzędzie badawcze wykorzystano kwestionariusz JSS (Spector's Job Satisfaction Survey), obejmujący zestaw 36 zagadnień punktowanych w skali 1-6. Uwzględniono 8 aspektów pracy w bibliotece: płace, możliwości awansu, stosunek do przełożonych, świadczenia, premie, procedury operacyjne, stosunek do współpracowników, ocena charakteru pracy. Suma wszystkich punktów charakteryzowała poziom zadowolenia z pracy. Respondenci wysoko ocenili charakter pracy i przełożonych, bez przesadnego entuzjazmu - płace i szanse awansu, nisko natomiast komunikację w miejscu pracy i procedury operacyjne. Najniższy poziom zadowolenia zaprezentowały osoby w wieku 31-40 lat, zwłaszcza w odniesieniu do płac, procedur operacyjnych, komunikacji międzyludzkiej, premii i opieki socjalnej. Zaobserwowano, że zadowolenie z pracy rośnie wraz z liczbą przepracowanych lat. Wśród bibliotekarzy z najdłuższym stażem pracy poniżej średniej oceniono tylko szanse awansu; z kolei premie to jedyna kategoria, którą bibliotekarze z najkrótszym stażem pracy ocenili powyżej średniej. Odnotowano podobną zależność również pomiędzy zadowoleniem z płacy i komunikacji międzyludzkiej a czasem pracy w obecnej instytucji oraz pomiędzy wysoką oceną możliwości awansu a posiadanym stopniem naukowym.

Postawy dyrektorów bibliotek duńskich wobec pracy są tematem następnego artykułu ${ }^{12}$. Organizatorem badań była Królewska Szkoła Bibliotekoznawstwa i Informacji Naukowej oraz Związek Zawodowy Bibliotekarzy, którzy dokonali analizy opinii osób zajmujących kierownicze stanowiska w bibliotekach akademickich i publicznych. Blisko $90 \%$ badanych było bardzo zadowolonych lub zadowolonych z pracy, wszyscy co najmniej dość zadowoleni, a im wyższe stanowisko, tym wyżej oceniono swoje zadowolenie. Na wysoką ocenę swojej placówki nie wpływały jednak takie czynniki, jak wiek, płeć, pensja czy rodzaj biblioteki, ale wysoka pozycja w hierarchii służbowej, dobra organizacja pracy, jasny system

11 E. Sierpe, Job satisfaction among librarians in English-language universities in Quebec, „Library and Information Science Research” vol. 21: 1999, no. 4, s. 479-499.

12 N. O. Pors, C. G. Johannsen, Job satisfaction and motivational strategies among library directors, „New Library World” vol. 103: 2002, no. 6, s. 199-208. 
odpowiedzialności, dobra komunikacja wewnętrzna, czas na planowanie i wpływ na realizację zadań. Negatywnie natomiast wpływała zależność od decyzji innych osób i zła koordynacja prac. Badanie wykazało też związek między satysfakcją z pracy kierownictwa bibliotek a stosowanymi narzędziami zarządzania, osiągnięciami, różnorodnością oferowanych usług. Sprzyja jej nacisk na wartości, dialog i wzajemny szacunek w relacjach z personelem. Najbardziej zadowoleni z pracy kierownicy uważali zarządzanie za psychologicznie trudne, zauważali konieczność balansowania między różnymi grupami interesów, z chęcią uczestniczyli w konferencjach i naradach roboczych.

Niels 0. Pors, współautor poprzedniego tekstu, rok później przedstawił kolejne badania zrealizowane wśród brytyjskich i duńskich dyrektorów bibliotek publicznych i akademickich ${ }^{13}$. Sondaż, którego celem było ustalenie czynników sprzyjających satysfakcji z pracy zawodowej, potwierdził wyniki sprzed roku, że na niezadowolenie nie mają wpływu takie determinanty, jak płeć badanego czy rodzaj biblioteki, istnieje natomiast wysoka korelacja między zadowoleniem z pracy a oceną poziomu stresu, jaki ona niesie: wśród osób zestresowanych w wysokim stopniu aż 31\% nie było zadowolonych z pracy. Badano też wpływ wolności (jasne zdefiniowanie odpowiedzialności, samodzielne ustalanie priorytetów, wpływ na decyzje i rodzaj wykonywanej pracy) na zadowolenie. Okazał się on dość wysoki - w grupie osób deklarujących najwyższy poziom swobody tylko $2 \%$ nie było zadowolonych z pracy, najwięcej niezadowolonych (15\%) nie miało większej wolności. Sprawdzano też, jaki wpływ na satysfakcję zawodową ma rodzaj pracy (rutynowa, administracyjna czy związana z kierowaniem ludźmi i ustalaniem polityki instytucji). Prace administracyjne zabierają $20 \%$ czasu dyrektorom duńskim i 46\% czasu angielskim. Nie wykazano korelacji między rodzajem zadań a zadowoleniem u bibliotekarzy brytyjskich, podczas gdy u duńskich była ona silna, tzn. osoby więcej czasu poświęcające na kierowanie ludźmi były bardziej zadowolone z pracy. Można to łączyć z faktem, że badani dyrektorzy brytyjscy kierują dużymi placówkami. Za ostatni istotny czynnik uznano elastyczny, preferujący nie sztywne zależności, a wartości i postawy, styl zarządzania. Wśród dyrektorów realizujących w niewielkim stopniu taki styl zarządzania było $44 \%$ osób nieusatysfakcjonowanych pracą, podczas gdy wśród osób preferujących tę metodę kierowania ludźmi niezadowoleni stanowili $9 \%$.

${ }^{13}$ N. O. Pors, Job satisfaction among library managers, cross-cultural study of stress, freedom and job conditions, „New Library World” vol. 104: 2003, no. 11/12, s. 464-473. 
Tematyka kolejnej pracy ${ }^{14}$ oscyluje wokół poszukiwania zależności między osobowością a zadowoleniem z pracy i pełnionych funkcji. Założono, że cechy osobowości mają wpływ na dopasowanie osoby do danego stanowiska pracy. Aby jednak określić, jaki wpływ mogą mieć na zadowolenie z jej wykonywania, przeprowadzono badania, które miały zgromadzić informacje na temat cech osobowych, zadowolenia z pracy i obranej ścieżki kariery ponad 1300 wykwalifikowanych pracowników amerykańskich bibliotek akademickich, publicznych, specjalnych, szkolnych, archiwów, katalogów, edukacji zdalnej itp. Po opracowaniu zebranych danych uzyskano silne korelacje między zmiennymi dotyczącymi osobowości a zadowoleniem z pracy i kariery. Największy wpływ (20\%) na satysfakcję z pracy miało 5 zmiennych: optymizm, emocjonalna stabilność, umiejętność pracy zespołowej, wizjonerskie podejście i chęć do pracy. Czynniki, takie jak optymizm, chęć do pracy, emocjonalna odporność i asertywność, powiązane były najsilniej (19\%) z odczuwaną satysfakcją z zajmowanego stanowiska. Wyniki dotyczące emocjonalnej odporności, chęci do pracy i optymizmu poddano następnie analizie hierarchicznej regresji w celu ich oceny jako mierników zadowolenia z pracy i kariery. Otrzymane rezultaty wskazały, iż istnieje silna zależność między osobowymi predyspozycjami bibliotekarzy a odczuwaną przez nich satysfakcją zawodową.

W 2008 r. ukazał się artykuł Elisy F. Topper ${ }^{15}$. Autorka powołuje się na sondaż „Library Journal” z 2007 r., według którego ponad 85\% badanych bibliotekarzy amerykańskich ze wszystkich typów bibliotek, gdyby mieli obecnie zaczynać karierę, wybrałoby swój zawód ponownie. Jeszcze wyższy poziom entuzjazmu do swojej pracy wykazują pracownicy bibliotek szkolnych (zdecydowałoby się na nią ponownie 94\%). Zadowolenie lub duże zadowolenie z pracy na obecnym stanowisku wyraziło $72 \%$ badanych, kolejne $23 \%$ było względnie usatysfakcjonowanych. Respondenci wskazywali też na szereg powodów do niezadowolenia, wśród których wymieniali najczęściej niskie płace, słabe dofinansowanie bibliotek, zły sposób zarządzania (niekompetencja przełożonych w kwestiach budżetowych i dotycząca zadań związanych ze specyfiką danego działu/instytucji, ich słabe przygotowanie do pełnienia funkcji kierowniczych) i nadmierną

${ }^{14}$ J. M. Williamson, A. E. Pemberton, J. Lounsbury, An investigation of career and job satisfaction in relation to personality traits of information Professional, „The Library Quarterly" vol. 75: 2005, no. 2, s. 122-141.

15 E. F. Topper, Job satisfaction in libraries, love it or leave it, „New Library World” vol. 109: 2008, no. 5/6, s. 287-290. 
biurokrację. Wyniki badania „Library Journal” pokrywają się z wnioskami uzyskanymi w innych sondażach. Zaobserwowane na ich podstawie tendencje to: zależność satysfakcji zawodowej od wieku (starsi pracownicy są bardziej zadowoleni niż młodzi), doświadczenia (im większe, tym wyższa satysfakcja), planów pracy w danej instytucji dłużej niż 5 lat, posiadanych kompetencji i wykształcenia zawodowego (analogiczne związki), charakteru pracy ( $\mathrm{w}$ działach informacji naukowej i gromadzenia poziom zadowolenia jest znacznie wyższy niż w innych) oraz możliwości kontaktów z czytelnikami (osoby pracujące bezpośrednio z użytkownikami wykazują znacznie wyższe zadowolenie niż pozostali). Zdaniem autorów cytowanych badań wskaźniki satysfakcji mogą wkrótce zacząć spadać, jeśli środowisko biblioteczne nie poradzi sobie z problemami chronicznego niedofinansowania tego sektora, a kadra kierownicza nie zdobędzie nowych kompetencji menedżerskich. Konieczne jest również przyciągnięcie do zawodu osób obeznanych z najnowszymi technologiami, które mogłyby wspomóc transformację i dostosowywanie bibliotek do wymogów nowej, cyfrowej ery.

Kolejne badania zostały opublikowane w $2010 \mathrm{r}^{16}$ Ich celem było ukazanie zależności pomiędzy zadowoleniem z pracy i zaangażowaniem w karierę zawodową a efektywnością pracowników bibliotek 24 państwowych uniwersytetów w Nigerii. Wyniki pomiarów dowiodły, że poziom zaangażowania respondentów w pracę jest wysoki i są oni z niej zadowoleni, wykazano również zależność pomiędzy poziomem satysfakcji a zaangażowaniem w wykonywanie obowiązków. Zdaniem autorów tak dobre rezultaty mogą wynikać z tego, że działalność badanych bibliotek i kwestia satysfakcji zawodowej bibliotekarzy stały się przedmiotem zainteresowania administracji i kierownictwa uczelni.

Analizując wyniki powyższych badań przedstawionych w czasopismach fachowych i uwzględnionych w bibliografii BABIN, można stwierdzić, że najczęściej przeprowadza się takie pomiary w dużych bibliotekach naukowych o rozbudowanej strukturze i licznym personelu. Najwięcej badań zrealizowano w Stanach Zjednoczonych, a ich wyniki omawia się najczęściej na łamach takich czasopism, jak „New Library World”, „College and Research Libraries” czy „The Library Quarterly”.

${ }^{16}$ G. Adio, S. Popoola, Job satisfaction and career commitment of librarians in federal university libraries in Nigeria, „Library Review” vol. 59: 2010, no. 3, s. 175-184. 


\section{Badania zadowolenia z pracy bibliotekarzy na gruncie polskim}

W Polsce także powstają prace podejmujące problematykę satysfakcji bibliotekarzy ${ }^{17}$. Dopiero jednak w ostatnich latach literatura fachowa przynosi wyniki tego typu badań, przy czym wciąż jeszcze nieliczna grupa placówek podejmuje się ich realizacji. W 2005 r. ukazał się artykuł Grażyny Bilskiej pt. Satysfakcja zawodowa bibliotekarzy - wyniki sondażu ${ }^{18}$. Autorka przedstawiła badanie, które miało na celu rozpoznanie czynników wpływających na zadowolenie bibliotekarzy oraz mających negatywny wpływ na ich satysfakcję. Respondentami byli bibliotekarze, którzy odpowiedzieli na ankietę zamieszczoną na stronie Elektronicznego Biuletynu Bibliotekarza (dalej: EBIB). Sondaż wykazał, że bibliotekarze najwyżej cenią sobie $\mathrm{w}$ pracy kontakt $\mathrm{z}$ czytelnikiem i jego zadowolenie, pozytywne opinie czytelników o umiejętnościach bibliotekarzy, rozmowy z czytelnikami, sukcesy studentów, możliwość pracy z dziećmi i ich radość. W następnej kolejności istotny był charakter pracy, ponieważ rozwija intelektualnie, zmusza do twórczego, kreatywnego myślenia i aktywności zawodowej, pozwala wprowadzać usprawnienia, umożliwia pierwszy kontakt z nowościami wydawniczymi i dostęp do zbiorów. Negatywnie na zadowolenie z pracy wpływa natomiast:

- brak szacunku dla zawodu bibliotekarza, niedocenianie działalności bibliotekarzy przez władze samorządowe i brak zrozumienia potrzeb bibliotek;

- za niskie płace w stosunku do obowiązków i umiejętności, niesprawiedliwe traktowanie pracowników w wynagradzaniu, brak świadczeń dodatkowych, niskie premie, nepotyzm, niedocenianie przez przełożonych, brak możliwości awansu i rozwoju zawodowego, stagnacja i zniechęcenie współpracowników, brak pracy zespołowej;

- niewystarczające finanse na działalność statutową;

- brak nowości czytelniczych;

- popołudniowe godziny pracy, brak dostępu do komputera;

17 R. Cybulski, Marketing wewnętrzny, „Bibliotekarz” 1995, nr 6, s. 15-19; E. B. Zybert, Szczęśliwy klient - szczęśliwy pracownik... czyli o satysfakcji bibliotekarzy, [w:] Zawód bibliotekarza dziś i jutro. Materiały z ogólnopolskiej konferencji Nałęczów 18-20 września 2003, Warszawa 2003, s. 49-61; B. Żołędowska-Król, dz. cyt., s. 48-59; J. Sadowska, Na marginesie zarządzania - satysfakcja, czyli zadowolenie z pracy, „Bibliotekarz” 2010, nr 1, s. 9-12.

${ }^{18}$ G. Bilska, Satysfakcja zawodowa bibliotekarzy - wyniki sondażu, „Poradnik Bibliotekarza" 2005, nr 7/8, s. 3-9. 
- warunki lokalowe;

- atmosfera w pracy.

Powyższą tematykę podjęto w 2007 r. na konferencji „Kultura organizacyjna w bibliotece", zorganizowanej przez Bibliotekę Uniwersytecką im. Jerzego Giedroycia w Białymstoku. Przedstawiono wówczas dwa referaty poświęcone zadowoleniu bibliotekarzy. Pierwszy, autorstwa Teresy Koniaszewskiej i Jadwigi Wojtczak, nosił tytuł: Satysfakcja z pracy a zakres obowiq̨zków pracownika biblioteki naukowe ${ }^{19}$. Badania przeprowadzone przez autorki wśród pracowników Biblioteki Głównej i Ośrodka Informacji Naukowo-Technicznej Politechniki Wrocławskiej miały na celu „zebranie informacji na temat czerpania satysfakcji na swoim stanowisku pracy, przyczyn podnoszenia kwalifikacji i podejmowania zadań dodatkowych oraz zaspokajania potrzeby samorealizacji" ${ }^{20}$. Jako najczęstszy powód niezadowolenia podawano niskie zarobki oraz brak okresowej oceny pracowników, która w sposób obiektywny wykazywałaby ich rozwój i wkład pracy. Satysfakcję ze swej pracy bibliotekarze czerpią zwłaszcza wtedy, kiedy stawia się przed nimi nowe wyzwania oraz daje im się możliwość samodzielnego podejmowania decyzji. Aż 74\% badanych nie chciałoby zamienić pracy wykonywanej na obecnym stanowisku, podobnie wyglądała odpowiedź na pytanie o zmianę zawodu lub miejsca pracy - 71\% nie chce ich zmienić.

Drugi referat został opracowany przez Agnieszkę Liszkę ${ }^{21} \mathrm{z}$ Biblioteki Głównej Akademii Ekonomicznej we Wrocławiu. Pomiarem objęto pięćdziesięciu młodszych bibliotekarzy bibliotek naukowych z całej Polski i - jak pisze autorka badań - 99\% młodszych bibliotekarzy lubi wykonywaną przez siebie pracę. Jednakże 30\% ankietowanych stwierdza, że praca ta nie spełniła ich oczekiwań. Do czynników wpływających na satysfakcję tej grupy zawodowej bibliotekarzy zaliczono motywację do pracy, udział w organizowaniu imprez i w działalności biblioteki na różnych szczeblach, przepływ informacji, komunikację między pracownikami, warunki pracy, zarobki, organizację pracy, atmosferę w pracy, pracę zespołową, równe traktowanie pracowników, współpracę ze starszą kadrą pracowników, wspieranie innowacyjności, pomysłowości i dzielenie się

19 T. Koniaszewska, J. Wojtczak, Satysfakcja z pracy a zakres obowiq̨zków pracownika biblioteki naukowej, [w:] Kultura organizacyjna w bibliotece, pod red. H. Brzezińskiej-Stec, Białystok 2008, s. 285-297.

20 Tamże, s. 292.

21 A. Liszka, „Być czy mieć” - wpływ kultury organizacyjnej na satysfakcję zawodowq i warunki pracy młodszych bibliotekarzy, [w:] Kultura organizacyjna w bibliotece..., s. 298$-308$. 
wiedzą. Od przełożonych pracownicy oczekują przede wszystkim otwarcia na nowe pomysły, dobrej organizacji pracy, motywacji do podnoszenia kwalifikacji, jedności w działaniu całej biblioteki, przykładności, promowania dzielenia się wiedzą, lepszego przepływu informacji. Bibliotekarze, którzy stwierdzili, że praca w bibliotece nie spełnia ich oczekiwań, jako powód podali mało pasjonujące zajęcie, środowisko pracy, brak motywacji do dalszego rozwoju, pracę w niewłaściwym dziale, wykonywanie pracy niezgodnej z kwalifikacjami zawodowymi, rodzaj wykonywanej pracy (czysto techniczne zajęcie), brak możliwości pogodzenia pracy $\mathrm{z}$ dokształcaniem się, monotonia pracy.

Dwa lata później, w 2009 r., Biblioteka w Białymstoku zrealizowała zbliżoną tematycznie konferencję „Marketing biblioteczny i zarządzanie zasobami ludzkimi w bibliotece", podczas której również poruszono temat satysfakcji pracowników. Celem badań zaprezentowanych w referacie Zwiq̨zek między skuteczna komunikacją w bibliotece naukowej a satysfakcja pracowników w świetle badań ankietowych. Marketing wewnętrzny Biblioteki Uniwersytetu Łódzkiego ${ }^{22}$ było określenie związku między skuteczną komunikacją w bibliotece naukowej a satysfakcją jej pracowników. W przygotowanym kwestionariuszu skoncentrowano się na następujących aspektach pracy: samodzielności, różnorodności, gratyfikacji finansowej, możliwości wykorzystania posiadanych umiejętności, możliwości kształcenia i awansu, ocenie i uznaniu za pracę, prestiżu, charakterystyce i ocenie zwierzchnika, związku pracy z życiem rodzinnym i relacjami interpersonalnymi. Jako czynniki pozytywnie wpływające na odczucia pracowników wyróżniono stabilność i pewność zatrudnienia, bogatą ofertę świadczeń socjalnych, dobre relacje koleżeńskie w zespole, podejmowanie wysiłków o coraz lepsze komunikowanie się w całej sieci bibliotecznej, działania integrujące wszystkich pracowników, poczucie dopasowania pracowników do wykonywanej pracy, możliwość awansu zawodowego. Negatywnie natomiast oceniono poziom wynagrodzenia, organizację czasu pracy oraz system oceniania i nagradzania pracowników.

Tematykę biblioteki jako miejsca pracy podjęto również w wystąpieniu: Satysfakcja pracowników Biblioteki Politechniki Łódzkiej a wize-

22 B. Leder-Niewola, G. Waliszewska, Zwiq̨zek między skutecznq komunikacja $w$ bibliotece naukowej a satysfakcją pracowników w świetle badań ankietowych. Marketing wewnętrzny Biblioteki Uniwersytetu Łódzkiego, [w:] Marketing wewnętrzny i zarządzanie zasobami ludzkimi w bibliotece, pod red. H. Brzezińskiej-Stec, J. Kudrawiec, Białystok 2010, s. 193-217. 
runek współczesnego bibliotekarza ${ }^{23}$. Na podstawie przeprowadzonego sondażu do czynników decydujących o atrakcyjności pracy w bibliotece zaliczono stabilność zatrudnienia, przyjazną atmosferę w pracy, kulturę organizacyjną, możliwość awansu oraz rozwoju zawodowego. Jak zauważono, w bibliotece występują także obszary problematyczne i źródła konfliktu, które mogą być przyczyną obniżenia nastrojów i zaangażowania w codzienną pracę. Do takich negatywnych czynników należy rutyna i monotonia pracy, biurokracja, plotki wśród pracowników, konflikty i rywalizacja między pracownikami, brak możliwości awansu, niefachowość przełożonych, atmosfera zastraszania pracowników, zbyt duże obciążenie pracą oraz zła organizacja pracy.

Wyczerpujące badania zadowolenia $\mathrm{z}$ pracy przeprowadzono w 2008 r. wśród personelu Biblioteki Uniwersytetu Warszawskiego ${ }^{24}$ (dalej: BUW), przy współpracy ze Studenckim Kołem Naukowym Badań Marketingowych „Chi Kwadrat” działającym w Instytucie Socjologii Uniwersytetu Warszawskiego (dalej: UW). Badania wykazały, że większość bibliotekarzy odczuwa satysfakcję ze swej pracy (odpowiedź tak wskazało 16\% respondentów, raczej tak 45\%) i nie zamierza jej zmieniać (79\%). Na satysfakcję z pracy wpływ mają: jej stabilność, zabezpieczenie socjalne, możliwość pracy zgodnej z wykształceniem, możliwość rozwoju i awansu zawodowego oraz udziału w szkoleniach organizowanych przez BUW. Wśród bibliotekarzy starszych satysfakcja z pracy w bibliotekach UW jest najwyższa. „21\% bibliotekarzy planuje zmianę pracy. Wśród nich największa część zamierza znaleźć pracę w innym zawodzie, dotyczy to jednak w większym stopniu mężczyzn niż kobiet, wśród kobiet bowiem znaczna część (30\%) chce znaleźć pracę w innej bibliotece (poza UW). Dla znacznej większości bibliotekarzy, którzy chcą odejść z bibliotek UW, powodem tej decyzji są zbyt niskie pensje. Niepokojące jest to, że występuje tu korelacja z wiekiem: niestety dotyczy to przede wszystkim bibliotekarzy młodych"25.

${ }^{23}$ A. Kazan, E. Skubała, Satysfakcja pracowników Biblioteki Politechniki Łódzkiej a wizerunek współczesnego bibliotekarza, [w:] Marketing wewnętrzny i zarzq̨dzanie zasobami ludzkimi..., s. 249-274.

${ }^{24}$ Badanie pracowników bibliotek UW. Raport Badawczy [on-line]. Warszawa: Biblioteka Uniwersytecka w Warszawie, 2008, 82 s. [dostęp 15 kwietnia 2012]. Dostępny w World Wide Web: http://www.buw.uw.edu.pl/buwnet/images/buwnet/start_aktualnosci/25_03_09/badanie_pracownikow_bibliotek_uw_raport.pdf.

25 R. Pawelec, Bibliotekarze i biblioteki Uniwersytetu Warszawskiego [on-line]. Biblioteka Uniwersytecka w Warszawie [dostęp 15 kwietnia 2012]. Dostępny w World Wide 
W lutym 2010 r. autorka artykułu przeprowadziła badanie satysfakcji wśród pracowników Biblioteki Uniwersytetu Pedagogicznego w Krakowie. Celem było rozpoznanie czynników wpływających na zadowolenie z pracy, które pozwolą określić obszary problematyczne oraz wprowadzić działania służące poprawie funkcjonowania biblioteki zgodnie ze wskazówkami personelu. Analizie poddano 35 ankiet wypełnionych przez 8 pracowników na stanowiskach kierowniczych i 27 bibliotekarzy. Do czynników wpływających na zadowolenie z wykonywanej pracy, ujętych w kwestionariuszu ankiety, zaliczono: klimat organizacyjny i atmosferę pracy, relacje ze współpracownikami w zespole, treść pracy i możliwość awansu. Najbardziej utrudnia efektywną pracę, zdaniem pracowników szeregowych, brak przepływu informacji, niesprzyjające warunki pracy, zła atmosfera w zespole pracowniczym, zła organizacja pracy, niewłaściwy stosunek przełożonych do podwładnych, brak możliwości wykazania się i podejmowania inicjatyw. Innego zdania byli kierownicy, którzy za najbardziej problematyczny obszar w bibliotece wskazali niesprzyjające warunki pracy, m.in. braki sprzętowe (uznało tak 63\% przełożonych). Wśród badanych $53 \%$ jest zadowolonych z pracy w bibliotece, a $41 \%$ poleciłoby ją jako dobre miejsce pracy. Zdecydowana większość - 67\% respondentów wiąże swoje losy zawodowe z badaną biblioteką. W najbliższej przyszłości zdaniem ankietowanych należałoby jednak poprawić system motywacyjny, system komunikowania poziomego między działami, wprowadzić zakresy obowiązków oraz podnosić kwalifikacje pracowników ${ }^{26}$.

\section{Podsumowanie}

Znajomość czynników wpływających na zadowolenie pracowników pozwala z pewnością na określenie obszarów konfliktowych i wprowadzenie działań naprawczych mających na celu zapobieganie pogłębianiu się poczucia niezadowolenia. Z przedstawionych wyżej badań wynika, że do najistotniejszych elementów świadczących o dużym zadowoleniu z wyko-

Web: http://www.buw.uw.edu.pl/buwnet/images/buwnet/start_aktualnosci/25_03_09/ ankieta_podsumowanie.pdf.

${ }^{26}$ Badania własne autorki. Wyniki przedstawiono na podstawie kwestionariuszy ankietowych wypełnionych przez pracowników Biblioteki Uniwersytetu Pedagogicznego w Krakowie. 
nywanej pracy należy treść pracy oraz możliwość rozwoju zawodowego. Oczywiście satysfakcja z pracy bibliotekarza zależy od sytuacji gospodarczej, uwarunkowań społecznych i kulturalnych w danym kraju. Interesująca jest jednak zbieżność opinii na ten temat wśród bibliotekarzy polskich oraz pracujących $\mathrm{w}$ innych krajach świata. W przypadku zadowolenia wskazywano często na czynniki ściśle związane z pracą w zespole, czyli właściwą komunikację, relacje interpersonalne, uznanie przełożonych. Najważniejszą przyczyną niezadowolenia w tej grupie zawodowej są natomiast niskie płace. Jednak mimo braku satysfakcji finansowej, osoby pracujące w bibliotekach często cenią swoją pracę i deklarują wysoki poziom zadowolenia z jej wykonywania. W przedstawionych sondażach podkreślano często, że wbrew pozorom wysokie zarobki nie są najważniejszym czynnikiem wpływającym na satysfakcję z pracy. Potwierdzają to badania zrealizowane wśród młodszych bibliotekarzy, którzy stanęli przed wyborem „być czy mieć"27. Na pytanie, czy lepiej jest zarabiać więcej, czy też mieć możliwość rozwoju na wysokim poziomie, połowa respondentów odpowiedziała, że woli zarabiać mniej, ale móc rozwijać się zawodowo, a $15 \%$ wstrzymało się od jednoznacznej odpowiedzi.

\section{Library as a workplace in staff opinion. Review of research}

ABSTRACT: The article aims to identify the factors affecting librarians' job satisfaction. The article presents foreign literature devoted to research into job satisfaction based on the "Analytical Bibliography of Library and Information Science". The second part presents Polish professional literature in this field as well as Polish libraries' initiatives in this area, e.g. research projects launched at the Warsaw University Library and the Library of the Pedagogical University in Cracow.

KEYwordS: "Analytical Bibliography of Library and Information Science", job satisfaction, Library of the Pedagogical University in Cracow, library staff, review of the literature, Warsaw University Library

27 A. Liszka, dz. cyt., s. 306-307. 